\section{Australian Journal of \\ Crop Science}

AJCS 14(12):1883-1888 (2020)

doi: 10.21475/ajcs.20.14.12.2650

\title{
Spatial distribution of physical attributes of a clayey Latosol under different
}

\section{management systems}

\author{
Simone Andreia Roehrs ${ }^{1}$, Aracéli Ciotti de Marins ${ }^{2}$, Deonir Secco ${ }^{1}$, Rogério Luís Rizzi ${ }^{3}$, Luiz Antônio Zanão \\ Júnior ${ }^{4}$, Pablo Chang ${ }^{1}$, Claudia Borgmann ${ }^{1}$, Bruna de Villa ${ }^{1}$, Lucas da Silveira ${ }^{5}$, Luciene Kazue Tokura ${ }^{{ }^{*}}$ \\ ${ }^{1}$ Post-Graduate Program in Energy Engineering in Agriculture, State University of Western Paraná, UNIOESTE, \\ Cascavel, PR, Brazil \\ ${ }^{2}$ Department of Mathematics, Federal Technological University of Paraná, Toledo, PR, Brazil \\ ${ }^{3}$ State University of Western Paraná, Cascavel, PR, Brazil \\ ${ }^{4}$ Paraná Agronomic Institute, Santa Tereza do Oeste, PR, Brazil \\ ${ }^{5}$ Post-Graduate Program in Agronomy, State university of Western Paraná, UNIOESTE, Marechal Cândido Rondon, \\ PR, Brazil
}

*Corresponding author: lucienetokura@gmail.com

\begin{abstract}
The use and management of the soil cause occasional changes in its physical properties; thus, altering its spatial variability. This work aimed to show the spatial distribution of physical attributes of a clay latosol under different management systems, through thematic maps of spatial distribution for values of these attributes. The experimental area consisted of three treatments: scarified no-tillage at $0.3 \mathrm{~m}$ depth (T1), no-tillage with $3 \mathrm{t} \mathrm{ha}^{-1}$ of plaster applied to the surface (T2) and; the control as traditional no-tillage system (T3). The attributes such as density, macroporosity, and microporosity in three soil layers were evaluated: 0-0.1; 0.1-0.2; and 0.2-0.3 $\mathrm{m}$. The analysis of the experimental results indicates that all physical attributes presented spatial dependence between the data, with higher density values (values ranged from 0.95 to $1.37 \mathrm{Mg} \mathrm{m}^{3}$ ) and lower macroporosity in areas with T1 (SPD with scarification) and T2 (SPD gypsum) management systems. However, in all treatments, the Macro values presented a volume above $10.51 \%$, which is above the limit value for good aeration and water movement in the soil. Treatment T3 (traditional SPD) showed favorable physical soil conditions, even after compaction.
\end{abstract}

Keywords: No-tillage system; porous space; density; spatial variability; thematic maps.

Abbreviations: $\mathrm{C}_{0}$ _ Nugget effect; $\mathrm{C}_{1}$ _Contribution; $\mathrm{C}=\mathrm{C}_{0}+\mathrm{C}_{1}$ _ Landing; $a_{-}$Range; LVdf _typical Dystroferic Red Latosol; lapar _ Agronomic Institute of Paraná; Embrapa _ Brazilian Agricultural Research Corporation; SPD _ No-tillage system; Lafis _ Laboratory of soil physics; Unioeste _ Western Paraná State University; $\mathrm{D}_{s_{-}}$Soil density; MSS _ Dry soil mass; VT _ Total volume; PT _ Total porosity; $\mathrm{D}_{\mathrm{p}_{2}}$ Particle density; Micro _ Microporosity; Macro _ Macroporosity; GD _ Degree of spatial dependence; $\mathrm{S}_{-}$Standard deviation; $\mathrm{S}^{2}$ - Variance; $\mathrm{CV}_{\text {_ }}$ Coefficient of variation; $\mathrm{C}_{0}$ _ Nugget effect; $\mathrm{C}_{0}+\mathrm{C}_{1}{ }_{-}$Landing; $\mathrm{FD}$ _ Dependency Range; EPP _ Pure nugget effect

\section{Introduction}

The soil has natural variability, given its formation and intrinsic characteristics. The use and management can also promote point changes, increasing the spatial variability of its attributes (Bottega et al., 2013), intensifying this heterogeneity. For these cases, classical statistics are not satisfactory to explain the influence of management on soil attributes, and geostatistics has proven to be an appropriate alternative to characterize and measure the spatial variation of soil properties (Bottega et al., 2013; Neto et al., 2015).

The knowledge of the diversity of an area enables the use of precision agriculture when the necessary corrective and management actions are pinpointed, reducing operating costs and the traffic of machines on the ground (Bottega et al., 2013), as a sustainable proposal.

Among the physical attributes of the soil, density, total porosity, macroporosity, and microporosity have certain spatial variability, either as a consequence of machine traffic, trampling animals or even by actions of the weather. Lima et al. (2015) studied the spatial variability of soil physical attributes in hillside areas under degradation, finding spatial dependence for all the attributes analyzed: water infiltration, soil density, and texture. According to the authors, the results found are important for the experimental planning of the studied area and should be taken into consideration in terms of the proposal for its management.

Silva et al. (2015) evaluated the variability of physical and chemical attributes of the soil and the production of beans. They concluded that among the attributes assessed the physical ones, such as the density and total porosity can best explain the spatial variability of bean production. 
The study of the spatial variability of these attributes is also important, because they are directly related to the hydraulic properties of the soil (Mesquita and Moraes, 2004; Fonseca et al., 2017), such as the hydraulic conductivity of saturated soil (Almeida et al., 2018) and water infiltration (Lima et al., 2015).

In geostatistics, the study of spatial variability is carried out through a sampling plan, in which a number of points are previously defined and the minimum spacing between samples are collected. For the study of variability, the semivariogram is usually being used, which measures the dependence between the sampling points, scattered in a reference space. Its objective is to perform the interpolation of values necessary for the construction of contour maps and surfaces employing kriging (Isaaks and Srivastava, 1989). The main components of a semivariogram are the nugget effect $\left(C_{0}\right)$, the contribution $\left(C_{1}\right)$, the landing $\left(C=C_{0}+C_{1}\right)$, and the range $(a)$.

There are three types of semivariogram, the true, which expresses the real dependence; the experimental, which is a result of the sampling points; and the theoretical one, which is adjusted according to some theoretical model (Guerra, 1998). Among the theoretical models, the spherical, Gaussian and exponential models stand out.

Based on the choice of the theoretical models with better data adjustment, the data is interpolated to determine the values of the measured variable in non-sampled points of the same area. Kriging is a data interpolation method that estimates the values of a certain random variable $Z(x)$ for non-sampled sites, enabling the construction of maps of a space S. According to Cressie (1992), this technique minimizes the estimated variance using an adjusted semivariogram and taking into account the stochastic dependence between the spatially distributed data.

Cross-validation consists of evaluating estimation errors, which allow comparing the estimated values with those sampled (Isaaks and Srivastava, 1989). This validation enables choosing the estimated model closest to the semivariance. The method consists of temporarily discarding a set of data, and for the same location estimation of a new set from the rest of the sample by Krigage. This procedure is repeated with all sets, comparing the estimated value with the sample value (Carvalho et al., 2012).

The final result of kriging is the interpolated surface of each variable, with its respective spatial distribution enabling the identification, location and coverage of extreme values, the degree of area homogeneity and the directions of the greater gradient. Based on the generated map, the presence of patterns or behaviors is feasible to infer (Guimarães et al., 2016).

Due to the importance of studying the spatial variability of soil attributes, this study aimed to evaluate the spatial dependence of density, macroporosity, and microporosity, through thematic maps of these attributes.

\section{Results and discussion}

\section{Descriptive statistics of treatments}

Tables 2, 3 and 4 present the results of descriptive statistics for the treatments evaluated. The Ds presented mean values between 1.02 and $1.17 \mathrm{Mg} \mathrm{m}^{3}$, similar to those found by Faraco et al. (2008). On the other hand, in T3 treatment (Table 4) we found lower Ds values, when compared to T1 (Table 2) and T2 treatments (Table 3), which may reveal that traditional no-till farming did not impose significant negative changes in soil structure. This effect is contrary to expectations, since recent experiments have shown a deterioration of the structure of soils managed with no-till for long periods (Cássaro et al., 2011; Suzuki et al., 2013; Didoné et al., 2014; Soracco et al., 2018). The nonoccurrence of an increase in the value of Ds can be explained by the fact that these are experimental plots, in which cover species called "structural recoverers" were cultivated since this is a long-term experiment.

The attribute with the highest coefficient of variation in all layers was Macro, with a higher CV of $27.23 \%$ in the second layer of T2 treatment, as shown in Table 3. This result was similar to that found by Drescher et al. (2016), with higher $\mathrm{CV}$ values for the same attribute. The first layer with $43.8 \%$ of CV takes into account all the treatments analyzed in the experiment. Guimarães et al. (2016) explained that the greater variability of this attribute may be a result of the methodology used in its calculation since its value is obtained by the difference between the PT and the Micro. For Ds and Micro, the coefficient of variation presented results close to or below $10 \%$, results similar to those found by Reichert et al. (2016).

The asymmetry values, close to zero, as well as the values found for kurtosis, reveal that the data are close to a normal distribution. This statement is confirmed by the Shapiro-Wilk test, with some exceptions, such as what occurred in the second layer of T3 treatment for Ds and Micro (Table 4). However, this is not a requirement for the application of geostatistical methods.

\section{Attributes of Soil Density (Ds), Macroporosity (Macro) and Microporosity (Micro) of the soil}

Table 5 presents the results of the spatial statistics for the soil attributes Ds, Macro and Micro in the three layers analyzed of the evaluated management system areas T1 (SPD with scarification), T2 (SPD gypsum) and T3 (SPD traditional).

The nugget effect $(\mathrm{CO})$ represents the discontinuity of the semivariogram, whereas its value should be zero in theory. The nullity of $\mathrm{CO}$ was occurred in some layers of the evaluated treatments. For example, it can be observed in all $\mathrm{T} 2$ depths of the variable Micro, besides values close to zero for the Ds, as can be observed in this experiment.

In the first and third layers of the Micro T1 treatment, the so-called pure nugget effect (PDP) was occurred. This result may indicate the non-detection of the structure of spatial variability at distances smaller than the shortest sampling distance (Kamikura et al., 2013).

The range value $(a)$ varied from 6 to 14 meters, and Micro showed lower range values. The Ds had a range of 10.1 to 14 meters, similar to that observed by Grego and Vieira (2005) and greater than those found by Kamikura et al. (2013) in the first two layers evaluated in the experiment.

Based on the degree of dependence classification by Mello et al. (2008), the Ds and Macro presented moderate to strong spatial dependence in almost all layers of the three treatments, except for Ds of the first layer of T3, with GD equal to $20.69 \%$ and the second layer of Micro of T15 treatment with GD of $23.91 \%$. The Micro did not show a degree of spatial dependence in layers 1 and 3 of the T1 treatment, while Kamimura et al. (2013) found strong dependence for this variable in all layers. 


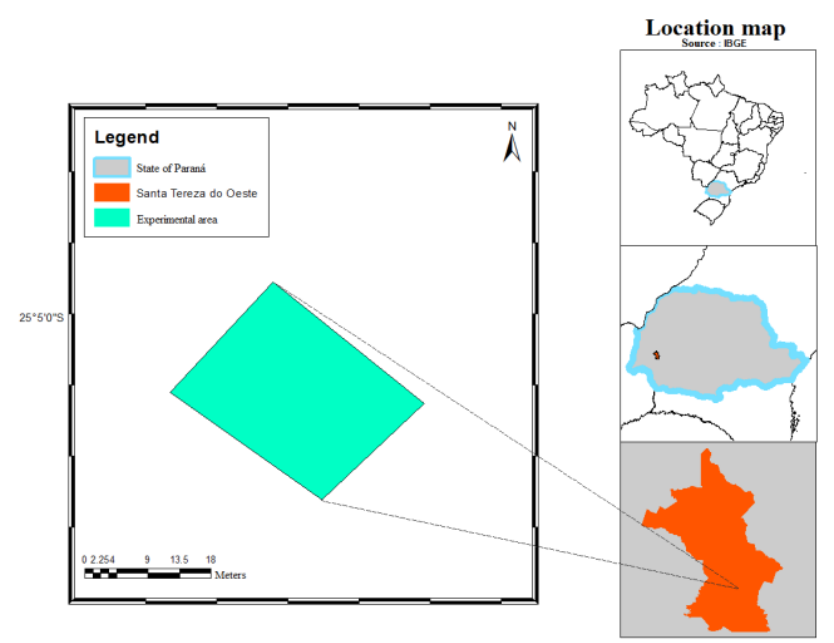

Fig 1. Location map of T1 treatment (25은 6,65" S and 53 35' 12,98" O).

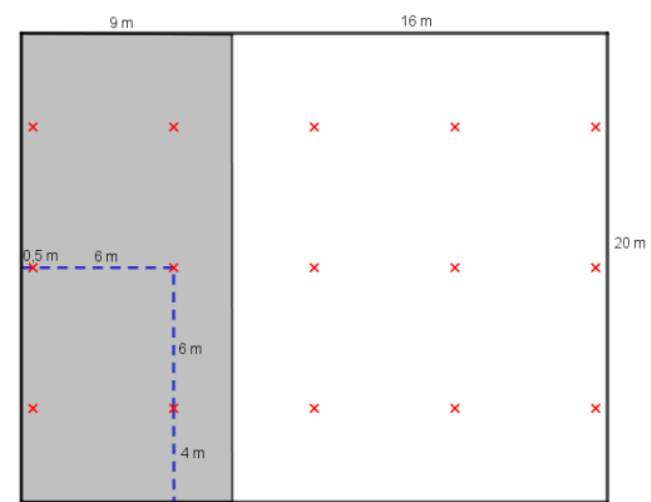

Fig 2. Point spacing breakdown for spatial variability analysis (gray stripe received three passes from of compacting roller in order to cause a density gradient in the soil).

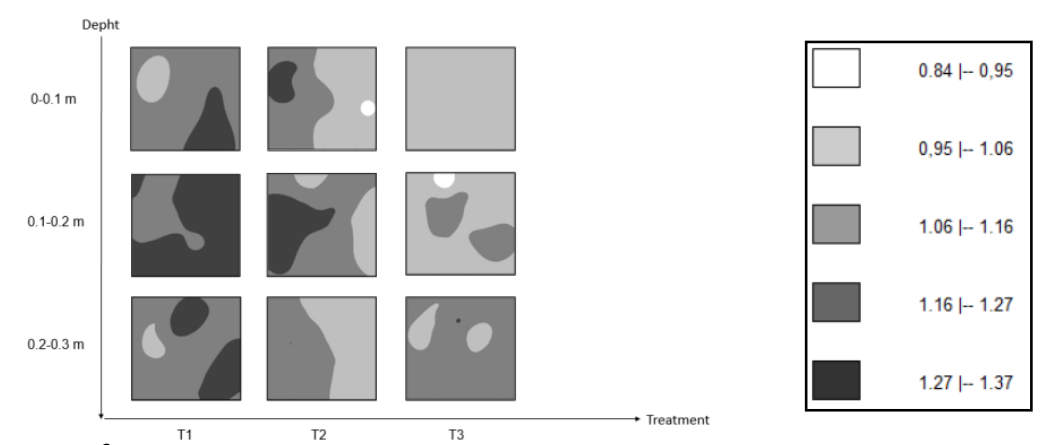

Fig 3. Surface maps of soil density, $\mathrm{Ds}\left(\mathrm{Mg} \mathrm{m}^{3}\right)$, for the three treatments, in the 0-0.1 layers; 0.1-0.2 and 0.2-0.3 $\mathrm{m}$. The colors in the image correspond to the Ds values $\left(\mathrm{Mg} \mathrm{m}^{3}\right)$, ranging from white $\left(0.84 \mathrm{Mg} \mathrm{m}^{3}\right)$ to dark grey $\left(1.37 \mathrm{Mg} \mathrm{m}{ }^{3}\right.$.
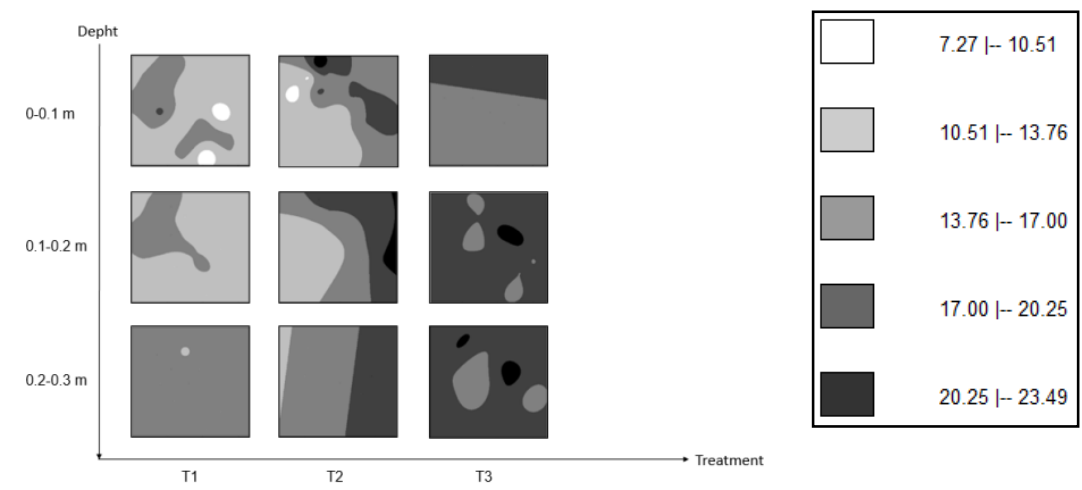

Fig 4. Surface maps of soil macroporosity, Macro (\%), for the three treatments, in the 0-0.1 layers; 0.1-0.2 and 0.2-0.3 m. The colors in the image correspond to the Macro values (\%), ranging from white $(7.27 \%)$ to dark grey $(23.49 \%)$. 


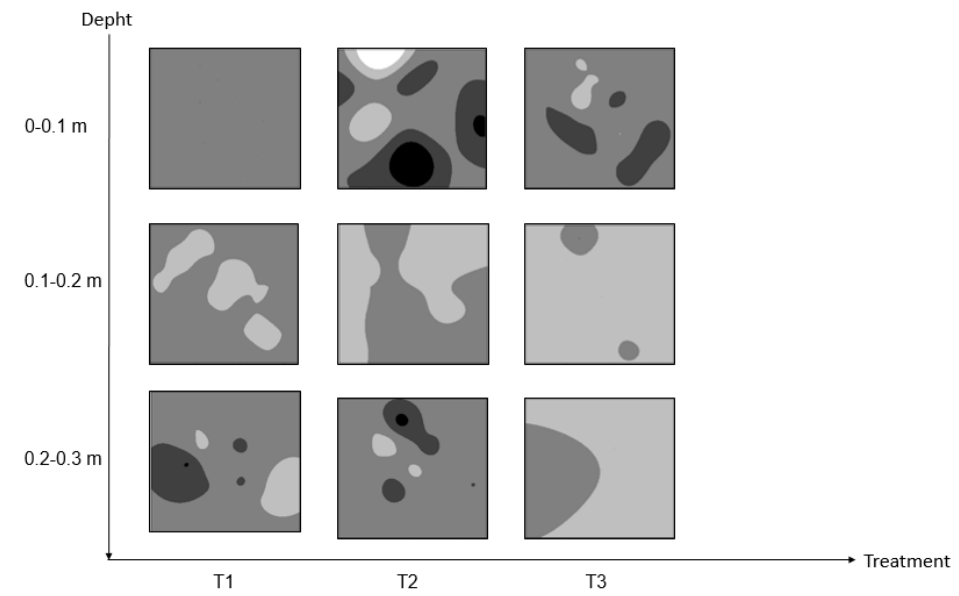

$35.08 \mid-38.30$

$38.30 \mid-41.52$

$41.521-44.75$

$44.75 \mid-47.97$

$47.97 \mid-51.19$

Fig 5. Surface maps of soil microporosity, Micro (\%), for the three treatments, in the 0-0.1 layers; 0.1-0.2 and 0.2-0.3 m. The colors in the image correspond to the Micro values (\%), ranging from white $(35.08 \%)$ to dark grey $(51.19 \%)$.

Figs 3, 4 and 5 present the kriging maps for the three layers of the three treatments analyzed. Figure 3 shows the spatial variability of the soil (Ds). The T1 treatment presented higher Ds values, followed by the $\mathrm{T} 2$ treatment, in all layers, when compared to the T3 treatment. The temporary effect of scarification explains this behavior in the case of $\mathrm{T} 1$ treatment. On the other hand, the higher Ds of $\mathrm{T} 2$ treatment concerning T3 treatment can be explained by the neutralization, in part, of aluminum ions that in this type of soil promote the dispersion of existing aggregates (Costa et al., 2007).

Besides, it is possible to observe a higher value of Ds in the 0.1-0.2 $\mathrm{m}$ layer in T1 and T2 treatments (Fig 3). It is in the subsurface layers that occur the greatest effects of the traffic of agricultural machinery and implements, especially in soils managed with the SPD (Nunes et al., 2014). In the T3 treatment, there was a slight increase in Ds along the layers, contrary to what was observed by Faraco et al. (2008) also in no-till farming.

The $\mathrm{T} 2$ treatment concentrated more Ds in all layers of the west side of the studied region, where there was the passage of the roller compactor. In the other treatments, deformation by the passage of the roller compactor was not clear. Variations in the Ds can be explained by intrinsic variables, as a result of natural changes in the soil or extrinsic such as machine traffic over the soil (Kamimura et al., 2013).

A similarity was observed between the Ds map of the second layer of $\mathrm{T} 1$ with the Macro map of this treatment. In the region where the highest Ds are concentrated, a lower volume of Macro was observed (Fig 4), highlighting the relationship between these important attributes. The result is similar to what observed by Santos et al. (2012) in the first layer (0-0.1 m), in Red Latosol with a texture similar to our study.

The T3 treatment presented the highest values of Macro in all layers, which may be related to the lowest values of Ds in this treatment (Reichert et al., 2007). However, in all treatments, the Macro values presented a volume above $10.51 \%$, which is above the limit for good aeration and water movement in the soil. Exceptions were the small regions in the first layer of $\mathrm{T} 1$ and $\mathrm{T} 2$ treatments, which had a value between 7.27 and $10.51 \%$.

The results presented in Fig 5 indicate that Micro remained constant in the soil profile for the three treatments, with a small decrease in the last two layers of T3. Reichert et al. (2007) stated that this attribute is not sensitive to deformations due to soil compaction. In Fig 5, it is also possible to identify the lower spatial continuity of this attribute, especially in the first layer of $\mathrm{T} 2$ treatment.

\section{Materials and methods}

\section{Experimental area}

The experiment was performed in the experimental area of the Agronomic Institute of Paraná, lapar, in the regional center of Santa Tereza do Oeste, Paraná, Brazil, located at latitude 25o 05' 6.65" S and longitude 53 35' 12.98" O. In the region, the climate is characterized as humid subtropical mesothermal, according to the classification of Köppen, Cfa (Caviglione, 2000), with an annual average rainfall of 1840 $\mathrm{mm}$ and relative air humidity between 75 to $80 \%$ (lapar, 2000).

\section{Soil characterization and climatological data}

According to the Brazilian Agricultural Research Corporation [Embrapa] (2018), the soil in the region is classified as typical Dystroferic Red Latosol, LVdf. The area has gently undulating slopes with values ranging from $0.21 \%$ to $5.41 \%$. Table 1 shows the granulometric analysis, indicating the texture class as very clayey.

\section{Characterization of treatments and plant materials}

The experimental work was carried out in the 2017/2018 harvest with soybean (The soybean cultivar used was the Lance IPRO with sowing of 15 seeds per linear meter and spacing of 45 centimeters between rows and fertilization of $300 \mathrm{~kg} \mathrm{ha}^{-1}$ of the formulation $08-22-08+6 \% \mathrm{Ca}+9 \% \mathrm{~S}$ ) cultivation and is part of a long-term experiment in an area, where management systems are evaluated. The experimental area consisted of three treatments: scarified no-tillage at $0.3 \mathrm{~m}$ depth (T1), no-tillage with $3 \mathrm{t}$ ha-1 of plaster applied to the surface (T2) and the control, traditional no-tillage system (T3). Fig 1 shows the map of the location of one of the treatments. The others were located in the same experimental area. 
In each of the areas analyzed, 15 georeferenced points were marked, from which undeformed soil samples from layers 00.1, 0.1-0.2 and 0.2-0.3 $\mathrm{m}$ were collected. The spacing between points was determined considering a number of points for a better representation of the area, as shown in Figure 2, with each area measuring $20 \times 25 \mathrm{~m}$. The T2 and T3 treatments received three passes of compacting roller in part of their area $(20 \times 9 \mathrm{~m})$ (Fig 2), to cause a density gradient in the soil.

The undeformed samples were collected with stainless steel volumetric rings, with a volume of approximately $98 \mathrm{~cm}^{3}(5$ $\mathrm{cm}$ in diameter and $5 \mathrm{~cm}$ and height), being allocated in aluminum cans and taken to the Laboratory of Soil Physics, Lafis, located in Unioeste, Cascavel, Paraná. In the laboratory, the samples were properly adjusted to the volume of the ring, removing the excess soil from the upper and lower parts of the ring, and then placed in trays for saturation for an approximate period of 24 hours. After saturation, they were placed in a sand column at a tension of 0.6 meters of water column for the removal of water from the macropores (Reinert and Reichert, 2006). Then, the samples were taken to a kiln with a temperature of $105^{\circ} \mathrm{C}$ until reaching a constant mass to extract the water in the micropores.

The soil density (Ds) was determined using the volumetric ring method, resulting from the ratio of dry soil mass (MSS) already discounted to the mass of the ring, by the total volume (VT) of the ring (Embrapa, 1997), according to the expression:

$$
D s\left(M g m^{-3}\right)=\frac{M S S}{V T}
$$

In turn, total porosity (PT) was evaluated through Ds and particle density (Dp) by the equation below proposed by Vomocil (1965):

$$
P T(\%)=\left(1-\frac{D s}{D p}\right) \times 100
$$

The expression was used to obtain the microporosity value (Micro):

$$
\operatorname{Micro}(\%)=\frac{M S U-M S S}{M S S} \times 100
$$

For the calculation of macroporosity (Macro), we used the equation:

$$
\operatorname{Macro}(\%)=P T-M i
$$

The particle density was determined by the volumetric flask method with alcohol.

\section{Statistical analysis}

The data were subjected to descriptive and spatial statistical analysis, with the assistance of software R ( $R$ Core Team, 2016). The Matheron semi-variate estimator (Matheron, 1962) was used to assess the existence and shape of the spatial dependence between the samples. After the construction of the experimental semivariograms, with a cutoff of $50 \%$ of the maximum distance between the sampled points, the theoretical models were adjusted by the ordinary least squares method and parameters $C_{0}, C_{1}, C$, and range $a$ were determined.

To determine the degree of spatial dependence (GD), the ratio between the structural variance and the level was used as follows (Mello et al., 2008):

$$
G D=\frac{C_{1}}{C_{0}+C_{1}} \times 100
$$

The classification of these values was according to Mello et al. (2008), and GD < 25\% denotes weak spatial dependence,
$25 \%<\mathrm{GD}<75 \%$ representing moderate spatial dependence, and GD $>75 \%$ is configured as strong spatial dependence. The thematic maps of the variables were generated by observing the dependence, through Krigagem, which estimates unbiased values for the nearby regions with minimum variance (Vieira, 2000).

\section{Conclusion}

The analysis of the experimental results indicates that all physical attributes presented spatial dependence between the data, with higher density values and lower macroporosity in areas with T1 (SPD with scarification) and T2 (SPD gypsum) management systems. Treatment T3 (traditional SPD) showed favorable physical soil conditions, even after compaction.

\section{References}

Abreu SL, Reichert JM, Reinert DJ (2004) Escarificação mecânica e biológica para a redução da compactação em Argissolo franco-arenoso sob plantio direto. Rev Bras Ciênc Solo. 28(3):519-531.

Almeida KSSA, da Silva Souza L, da Silva Paz VP, dos Santos Silva FT, Santos DN, Pereira JDSL (2018) Variabilidade espacial da condutividade hidráulica do solo saturado em Latossolo amarelo distrocoeso, no município de Cruz das Almas. Irriga. 22(2):259-274.

Bottega EL, de Queiroz DM, de Carvalho Pinto FDA, de Souza CMA (2013) Variabilidade espacial de atributos do solo em sistema de semeadura direta com rotação de culturas no cerrado brasileiro. Rev Ciênc Agron. 44(1):1-9.

Carvalho JRP, Assad ED, Pinto HS (2012) Interpoladores geoestatísticos na análise da distribuição espacial da precipitação anual e de sua relação com altitude. Pesq Agropec Bras. 47(9):1235-1242.

Cássaro FAM, Borkowski AK, Pires LF, Rosa JA, da Costa Saab $S$ (2011) Characterization of a Brazilian clayey soil submitted to conventional and no-tillage management practices using pore size distribution analysis. Soil Till Res. 111(2):175-179.

Caviglione JH, Kiihl LRB, Caramori PH, Oliveira D (2000) Cartas climáticas do Paraná. Londrina: lapar.

Costa, CDDO, Alves MC, Sousa ADP (2015) Movimento de Água e porosidade dos solos de uma sub-bacia hidrográfica no noroeste do estado de São Paulo. Irriga. 20(2):304-318.

Cressie N (1992) Estatistics for spatial data. Terra Nova. 4:613-617.

Didoné EJ, Minella JPG, Reichert JM, Merten GH, Dalbianco $L$, de Barrros CAP, Ramon $R$ (2014) Impact of no-tillage agricultural systems on sediment yield in two large catchments in Southern Brazil. J Soils Sediments. 14(7):1287-1297.

Drescher MS, Reinert DJ, Denardin JE, Gubiani PI, Faganello A, Drescher GL (2016) Duração das alterações em propriedades físico-hídricas de Latossolo argiloso decorrentes da escarificação mecânica. Pesq Agropec Bras. 51(2):159-168.

Embrapa - Empresa Brasileira de Pesquisa Agropecuária (1997) Manual de métodos de análise de solos. 2 ed. Rio de Janeiro: Centro Nacional de Pesquisa de Solos. 212p.

Embrapa - Empresa Brasileira de Pesquisa Agropecuária (2018) Sistema Brasileiro de Classificação de Solos. 5 ed. Brasília: Embrapa. 355p. 
Faraco MA, Uribe-Opazo MA, Silva EAA, Johann JA, Borssoi JA (2008) Seleção de modelos de variabilidade espacial para elaboração de mapas temáticos de atributos físicos do solo e produtividade da soja. Rev Bras Ciênc Solo. 32(2):463-476.

Fonseca LDAM, Lani JL, Santos GRD, Ferreira WPM, Santos AMRT (2017) Variability in soil physical properties in landslide-prone areas. Acta Sci Agron. 39(1):109-118.

Grego CR, Vieira SR (2005) Variabilidade espacial de propriedades físicas do solo em uma parcela experimental. Rev Bras Ciênc Solo. 29(2):169-177.

Guerra PAG (1988) Geoestatística operacional. Brasília: MME/DNPM. 145p.

Guimarães WD, Junior JG, Marques EAG, Santos NT, Fernandes RBA (2016) Variabilidade espacial de atributos físicos de solos ocupados por pastagens. Rev Ciênc Agron. 47(2):247-255.

lapar - Instituto Agronômico do Paraná (2000) Cartas Climáticas do Estado do Paraná. Londrina: lapar. <http://www.iapar.br/modules/conteudo/conteudo.php? conteudo=677>

Isaaks EH, Srivastava M (1989) An introduction to applied geostatistics. New York: Oxford University Press. 413p.

Kamimura KM, Santos GRD, Oliveira MSD, Dias Junior MDS, Guimarães PTG (2013) Variabilidade espacial de atributos físicos de um Latossolo vermelho-amarelo, sob lavoura cafeeira. Rev Bras Ciênc Solo. 37(4):877-888.

Lima FV, da Silva Silvino G, de Souza Melo RS, Lira EC, de Souza Ribeiro T (2015) Variabilidade espacial de atributos físicos do solo em área de encosta sob processo de degradação. Rev Caatinga. 28(4):53-63.

Matheron G (1962) Traite de geoestatistique appliquée, 1. Paris: Editions Technip. 333p.

Mello CR, Viola MR, de Mello JM, da Silva AM (2008) Continuidade espacial de chuvas intensas no estado de Minas Gerais. Ciênc Agrotec. 32(2):532-539.

Mesquita MDGBD, Moraes SO (2004) A dependência entre a condutividade hidráulica saturada e atributos físicos do solo. Ciênc Rural. 34(3):963-969.

Neto FDCC, Sampaio FDMT, da Costa Veloso ME, Matias SSR, Andrade FR, Lobato MGR (2015) Variabilidade espacial da resistência à penetração em Neossolo litólico degradado. Rev Bras Ciênc Solo. 39(5):1353-1361.

Nunes MR, Pauletto EA, Denardin JE, Faganello A, Pinto LFS, Scheunemann T (2014) Persistência dos efeitos da escarificação sobre a compactação de Nitossolo sob plantio direto em região subtropical úmida. Pesq Agropec Bras. 49(7):531-539.

Nunes MR, Denardin JE, Pauletto EA, Faganello A, Pinto LFS (2015) Mitigation of clayey soil compaction managed under no-tillage. Soil Till Res. 148:119-126.

R Core Team (2016) R: A language and environment for statistical computing. Vienna: R Foundation for Statistical Computing.

Reichert JM, Suzuki LEAS, Reinert DJ (2007) Compactação do solo em sistemas agropecuários e florestais: Identificação, efeitos, limites críticos e mitigação. In Ceretta CA, Silva LS, Reichert JM (Ed.), Tópicos em ciência do solo. Viçosa: Sociedade Brasileira de Ciência do Solo. 49-134.

Reichert JM, da Rosa VT, Vogelmann ES, da Rosa DP, Horn R, Reinert DJ, Sattler A, Denardin JE (2016) Conceptual framework for capacity and intensity physical soil properties affected by short and long-term (14 years) continuous no-tillage and controlled traffic. Soil Till Res. 158:123-136.

Reinert DJ, Reichert JM (2006) Propriedades físicas do solo. Universidade Federal de Santa Maria. 18p.

Silva ENS, Montanari R, Panosso AR, Rodrigues Correa A, Tomaz PK, Ferraudo AS (2015) Variabilidade de atributos físicos e químicos do solo e produção de feijoeiro cultivado em sistema de cultivo mínimo com irrigação. Rev Bras Ciênc Solo. 39(2):598-607.

Santos D, de Souza EG, Nóbrega L, Bazzi CL, Gonçalves A (2012) Variabilidade espacial de atributos físicos de um Latossolo Vermelho após cultivo de soja. Rev Bras Eng Agríc Ambient. 16(8):843-848.

Soracco CG, Lozano LA, Villarreal R, Melani E, Sarli GO (2018) Temporal variation of soil physical quality under conventional and no-till systems. Rev Bras Ciênc Solo. 42:1-12.

Suzuki LEAS, Reichert JM, Reinert DJ (2013) Degree of compactness, soil physical properties and yield of soybean in six soils under no-tillage. Soil Res. 51(4):311-321.

Vieira SR (2000) Geoestatística em estudos de variabilidade espacial do solo. In Novais RF, Alvarez VH, Schaefer CEGR (Ed.). Tópicos em ciência do solo. Viçosa: Sociedade Brasileira de Ciência do Solo. 1-53.

Vomocil JA (1965) Porosity. In Black CA (Ed.). Methods of soil analysis. Part 1. Pphysical and mineralogical properties, including statistics of measurement and ampling. Madison: American Society of Agronomy. 299-314. 